\title{
The poison is on the table: an analysis of the pesticides present in the food of
}

\section{Brazilians}

\section{O veneno está à mesa: uma análise dos agrotóxicos presentes na comida dos brasileiros}

El veneno está sobre la mesa: un análisis de los pesticidas presentes en la comida de los brasileños

Received: 08/31/2021 | Reviewed: 09/08/2021 | Accept: 09/13/2021 | Published: 09/14/2021

\author{
Ana Carolina Araújo Silva \\ ORCID: https://orcid.org/0000-0002-1619-5928 \\ Universidade Federal de São João Del-Rei, Brasil \\ E-mail: araujoanac7@gmail.com \\ Danúbia Domingos Epifânio \\ ORCID: https://orcid.org/0000-0002-6018-3174 \\ Universidade Federal de São João Del-Rei, Brasil \\ E-mail: danubiiadomingos@gmail.com \\ Mariana Linhares Pereira \\ ORCID: https://orcid.org/0000-0002-3214-2789 \\ Universidade Federal de São João Del-Rei, Brasil \\ E-mail: marianapereira@ufsj.edu.br \\ Farah Maria Drumond Chequer \\ ORCID: https://orcid.org/0000-0003-3514-2132 \\ Universidade Federal de São João Del-Rei, Brasil \\ E-mail: farahchequer@ufsj.edu.br
}

\begin{abstract}
Brazil is the world's largest consumer of pesticides. To monitor the quality of food sold in the country, the Program for Analysis of Pesticide Residues in Food (Programa de Análise de Resíduos de Agrotóxicos em Alimentos - PARA) was created, responsible for carrying out analyzes of these foods and providing annual reports. The objective of this study was to carry out a survey of the information contained in these reports on the residues of pesticides found on unsatisfactory samples (unauthorized pesticides and/or above the permitted limit). This is a descriptive documentary study, based on the reports available (2001 to 2018). Information was collected on the pesticides that most appeared among the samples considered unsatisfactory and their possible damage to human health. Strawberries, bell peppers, and cucumbers presented the largest numbers of samples unsatisfactory, mostly because of the presence of pesticides unauthorized. The pesticides that have been repeated the most irregularly were chlorpyrifos, carbendazim, acefate and metamidophos, the latter has been banned since 2011 in Brazil. Evidence show that such pesticides are toxic to the human organism. Measures are needed to better control and inspect food and pesticides sold in Brazil, also raise awareness among the population and rural producers.
\end{abstract}

Keywords: Pesticide; Residue; Food; Risk to human health.

\section{Resumo}

O Brasil é o maior consumidor mundial de agrotóxicos. Para acompanhar a qualidade dos alimentos comercializados no país, foi criado o Programa de Análise de Resíduos de Agrotóxicos em Alimentos (PARA) responsável pela a realização de análises desses alimentos e disponibilização de relatórios anuais. O objetivo deste estudo foi realizar um levantamento das informações contidas nesses relatórios sobre os resíduos de agrotóxicos encontrados em amostras insatisfatórias (agrotóxicos não autorizados e/ou acima do limite permitido). Trata-se de um estudo descritivo documental, baseado nos relatórios disponíveis (2001 a 2018). Foram levantadas informações sobre os agrotóxicos que mais apareceram entre as amostras insatisfatórias e seus possíveis danos à saúde humana. Morango, pimentão e pepino apresentaram os maiores números de amostras insatisfatórias, a maioria destas sendo consideradas insatisfatórias, pela presença de agrotóxicos que não tinham o uso autorizado. Os agrotóxicos que mais se repetiram irregularmente foram clorpirifós, carbendazim, acefato e metamidofós, este último tendo seu uso proibido desde 2011 no Brasil. Há evidências de que tais agrotóxicos são tóxicos para o organismo humano. São necessárias medidas para um melhor controle e fiscalização dos alimentos e agrotóxicos comercializados no Brasil, além da conscientização da população e produtores rurais.

Palavras-chave: Agrotóxico; Resíduo; Alimento; Risco à saúde humana. 


\section{Resumen}

Brasil es el mayor consumidor mundial de pesticidas. Para monitorear la calidad de los alimentos vendidos en el país, se creó el Programa de Análisis de Residuos de Plaguicidas en los Alimentos (Programa de Análise de Resíduos de Agrotóxicos em Alimentos - PARA), encargado de realizar análisis de estos alimentos y brindar informes anuales. El objetivo de este estudio fue realizar un relevamiento de la información contenida en estos informes sobre los residuos de plaguicidas encontrados en muestras insatisfactorias (plaguicidas no autorizados y/o por encima del límite permitido). Se trata de un estudio documental descriptivo, basado en los informes disponibles (2001 a 2018). Se recopiló información sobre los plaguicidas que más aparecieron entre las muestras consideradas insatisfactorias y su posible daño a la salud humana. Las fresas, pimientos morrones y pepinos presentaron el mayor número de muestras insatisfactorias, principalmente debido a la presencia de pesticidas no autorizados. Los plaguicidas que se han repetido de forma más irregular han sido el clorpirifos, carbendazim, acefato y metamidofos, este último prohibido desde 2011 en Brasil. La evidencia muestra que tales pesticidas son tóxicos para el organismo humano. Se necesitan medidas para un mejor control e inspección de los alimentos y plaguicidas vendidos en Brasil, además de sensibilizar a la población y los productores rurales.

Palabras clave: Plaguicida; Residuo; Comida; Riesgo para la salud humana.

\section{Introduction}

To increase production yield, pesticides are widely used with the aim of keeping crops healthy and preventing destruction by infestations/diseases (Nougadère, 2020). Its use in several cultures, mainly fruits and vegetables, has the permanence of variable amounts of these products as consequence, which can trigger risks to human health (Knežević and Serdar, 2011). Thus, to monitor the presence of pesticide residues in food before it reaches the market, it is necessary to analyze these products (Gómez-Ramos et al., 2020).

Since 2008, Brazil has ranked first as the world's largest consumer of pesticides, surpassing the United States. In a decade, the national pesticide market accumulated a growth of $190 \%$, a worrying fact when compared to the world growth, which was $93 \%$ in the same period (Carneiro, 2015).

Studies relate with the presence of pesticides in food and the risks their daily consumption can cause to the health of the general population are still scarce, but some evidence already points to toxicity triggered by this type of exposure. As an example, the study by Chiu et al. (2018), in which women who underwent infertility treatment and who consumed fruits and vegetables with a high content of pesticide residues, were less likely to become pregnant. Other study with men who were undergoing infertility treatment, the consumption of fruits and vegetables with high levels of pesticide residues, was associated with a lower count and percentage of morphologically normal sperm (Chiu et al., 2015). Jallow and collaborators (2017) investigated the presence of pesticide residues in fruits and vegetables of common consumption in Kuwait, and demonstrated that $21 \%$ of the analyzed samples contained residues above the Maximum Residue Limit (MRL) by the Codex Alimentarius, which suggests potential risk to human health. Pirsaheb et al. (2015) demonstrated the presence of two or more organochlorine pesticides in breast milk samples, relating this fact to the consumption of foods that contained residues of these compounds..

In Brazil, 1512 notifications of pesticide poisoning from agricultural use were registered in the Notifiable Diseases Information System (Sistema de Informação de Agravos de Notificação - SINAN) in 2020 (DATASUS, 2020). Whether due to environmental contamination or occupational use, the entire population is exposed to pesticides, and the national scenario tends to worsen, since 474 and 493 substances were registered by the Ministry of Agriculture, Livestock and Supply (Ministério da Agricultura Pecuária e Abastecimento - MAPA) throughout 2019 and 2020, respectively, these numbers being the highest in history (Grigori, 2021). Several changes in the population's food profile were also noted on 2020 as a result of the COVID-19 pandemic, one of them being the increased consumption of over-processed foods (Leão, 2021)

Among the records, a new pesticide in Brazil stands out. Sulfoxaflor has already been banned in the United States as it presents potential damage to bees (Brasil, 2019), which represents a major concern because bees are the main responsible for pollination in most ecosystems, and in Brazil about $60 \%$ of plants grown for food depend on pollination (Grigori, 2019). 
Thus, there is a clear need to investigate the consequences that food consumption of pesticides can trigger in the human body, as well as to develop programs to monitor the quality of food sold to the population. Aiming at the latter, the Program for Analysis of Pesticide Residues in Food (Programa de Análise de Resíduos de Agrotóxicos em Alimentos - PARA) was created, coordinated by the National Health Surveillance Agency (Agência Nacional de Vigilância Sanitária - ANVISA), linked to the Ministry of Health. PARA assesses the levels of pesticide residues in food, providing reports of its analyzes (ANVISA, 2008). There are currently reports for the period 2001 to 2018.

In view of the above, the objective of this study was to carry out a survey of the information contained in the PARA reports for the years 2001 to 2018, on the presence of pesticides not authorized for the crop and/or above the MRL allowed in food.

\section{Methodology}

A qualitative documentary study was carried out, analyzing secondary data contained in the reports issued by the Program for Analysis of Pesticide Residues in Food published and made available on the website https://www.gov.br/anvisa/ptbr/assuntos/agrotoxicos/programa-de-analise-de-residuos-em-alimentos. According to Ludke e Andre (1986, chap. 3) "documentary analysis can be a valuable technique for approaching qualitative data, either by complementing the information obtained by other techniques, or by unveiling new aspects of a theme or problem".

The data were collected from the year 2001, when PARA was created, with the objective of continuously evaluate the levels of pesticide residues in foods of plant origin that arrive at the consumer's table. All reports issued by PARA available from 2001 to 2020 have been included.

In order to outline the profile of the main pesticide residues found in food, the documentary analysis of each report was read by two researchers, independently. The following variables were collected: year of publication of the report, type of food, samples considered unsatisfactory, and the types of pesticides found. When available in the reports, information was collected separately from samples above the MRL, and samples with pesticide residues not allowed.

The samples were considered unsatisfactory when they presented pesticides not authorized for use on the crop and/or pesticides above the MRL established, with the sum of these two parameters providing the total of unsatisfactory samples. For data analysis and interpretation, a database in the form of spreadsheets was built using Microsoft Office Excel 2016.

Based on this data collection, a literature narrative review was performed on the main pesticides found in unsatisfactory samples and those that were found in the samples more often over the years analyzed. According to Elias (2012), it "enables the construction of articles in which authors can carry out broader critical analyzes and interpretations, making it possible to understand the "state of the art' of a given subject, from a theoretical or contextual point of view". was collected on the possible risks of their use to human health. The following databases were used: Science Direct, Web of Science, Scielo, and PubMed. The data search was carried out from April 2019 to May 2021, for complete articles available in English or Portuguese. The keywords used in the search for articles were: chlorpyrifos, carbendazim, acephate, methamidophos, glyphosate, toxicity, pesticide, food, exposure and residue with the booleans AND and OR.

\section{Results}

During the years 2001 to 2018, ANVISA issued eight reports with the results found by PARA, the first report referring to the years 2001 to 2007 , the second for 2008, the third from 2009, the fourth for 2010, the fifth from 2011 to 2012 , this 1 atter received a complementary report with the results of the analysis of six more crops (zucchini, lettuce, beans, cornmeal, tomatoes and grapes). The seventh report issued presents the results for the years 2013 to 2015. The eighth and last report to 
date, presents results for the years 2017 to 2018, and according to information made available within, 2016 was dedicated to restructuring to implement improvements to PARA, a fact that may justify the absence of food analysis results for the year in question.

When comparing the information made available by PARA reports over the years, it is possible to notice that the number of crops (Figure 1) and samples analyzed (Figure 2) underwent slight variations between the years 2001 to 2007.

Figure 1: Total crops analyzed by the Program for Analysis of Pesticide Residues in Food - PARA (2001-2018).

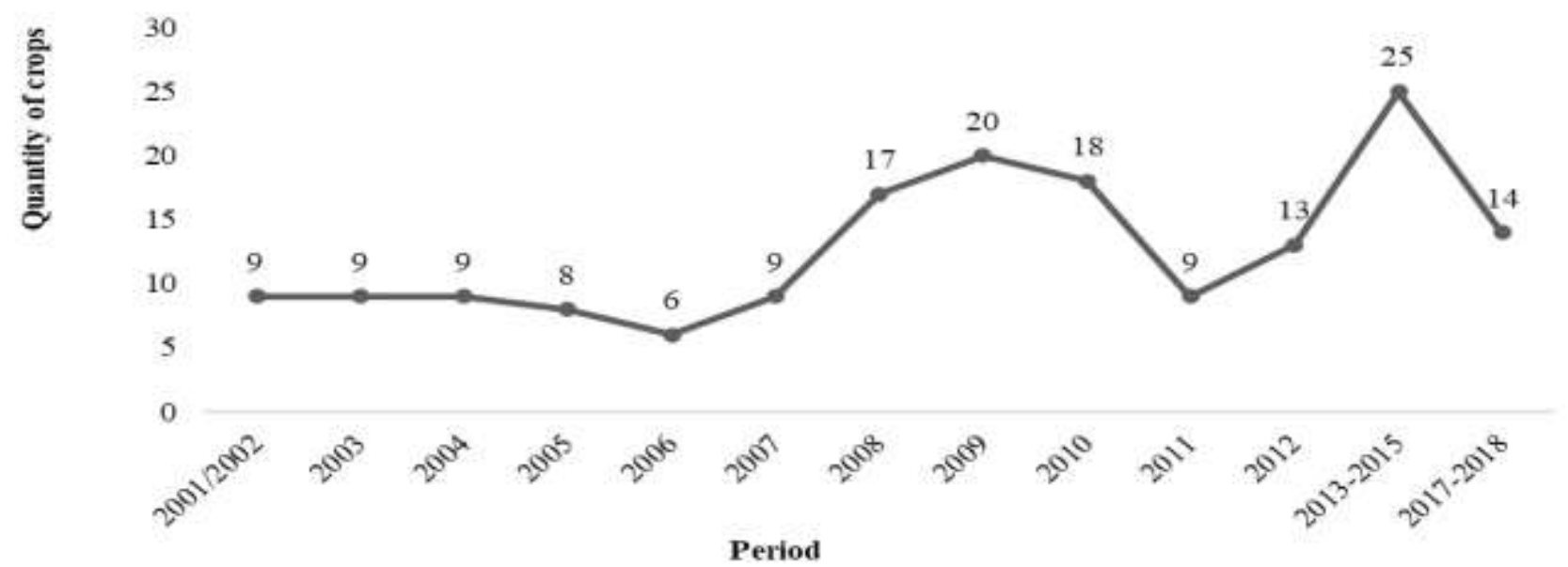

Source: Program for Analysis of Pesticide Residues in Food - PARA (2001-2018).

Figure 2: Total samples analyzed by the Program for Analysis of Pesticide Residues in Food - PARA (2001-2018).

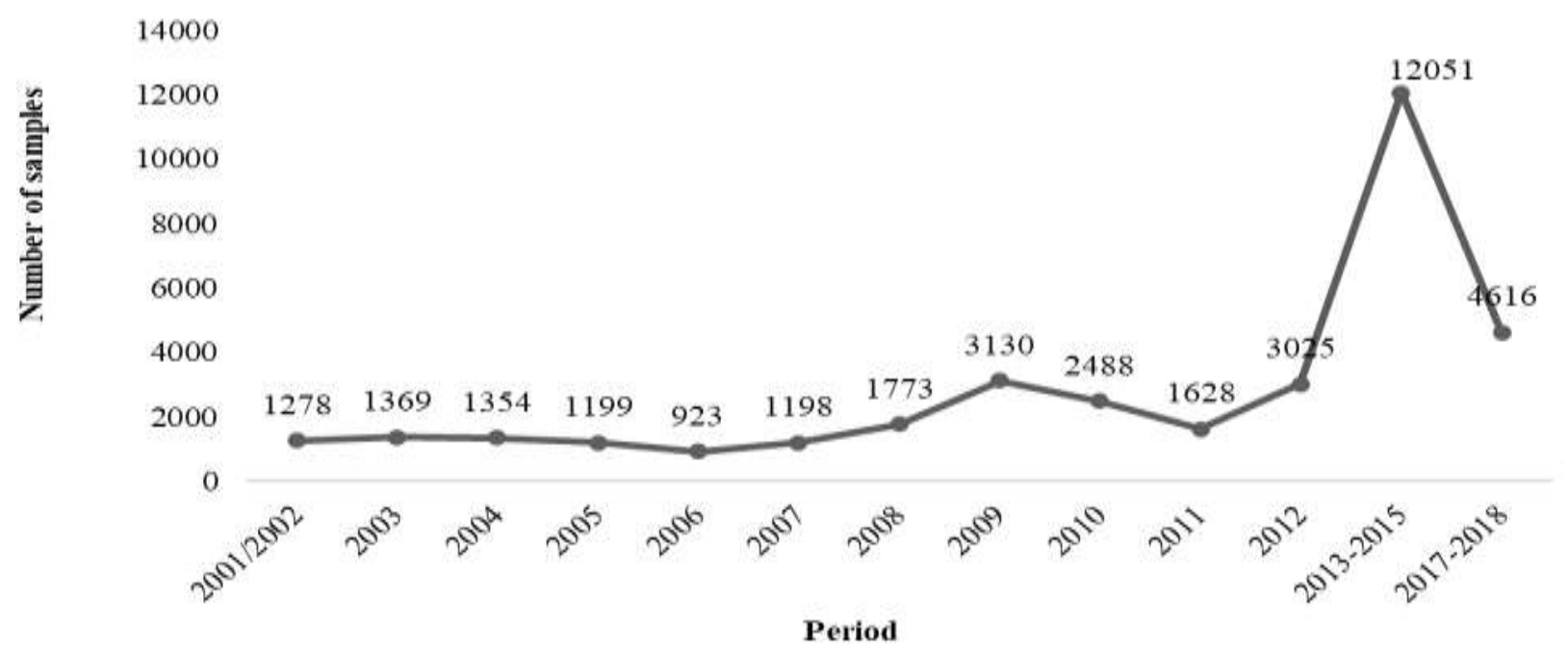

Source: Program for Analysis of Pesticide Residues in Food - PARA (2001-2018).

The 2017-2018 report only contains data from 2017, results from 2018 yet to be published.

An increase in the total of analyzed crops could be observed in the years 2008, 2009, 2010 and 2013-2015 (Figure 1). And an increase in the number of samples analyzed occurred in the years 2008, 2009 and 2013-2015, with emphasis on the years 2013 to 2015, in which more than 12,000 samples were analyzed (Figure 2). This was due to the greater investments in the program since 2008, with an expansion in the number of samples, crops, and pesticides analyzed, due to the participation of 
new states and the hiring of private laboratories, as a consequence of the structural problems of the public laboratories that are part of PARA.

On the other hand, although in 2010 more than 2,000 samples were analyzed, this number dropped compared to 2009 (Figure 2), a fact caused by the absence of products at collection points and deterioration of the samples before arriving at the laboratories. In the years 2011 and 2012, there was also a reduction in crops (Figure 1) and samples (Figure 2), compared to previous years (2008, 2009 and 2010) and later (2013-2015 and 2017-2018), and this occurred due to the use only of public laboratories, which in the course of the process presented several problems that compromised the analyzes, such as equipment breakdown, lack of inputs, and the need to renovate the physical facilities.

In the last PARA report, for the years 2017 to 2018, there was also a reduction in the analyzed crops, and according to information contained in the report itself, this decrease occurred because it was issued in different cycles, with new crops being analyzed for each cycle. Although in those years more than 4,000 samples were analyzed, a much higher number than in the years 2001-2012, in which the minimum of samples analyzed was 923 and the maximum of 3,130, they did not achieve the same success in the number of samples analyzes in the 2013-2015 report $(n=12051)$ (Figure 2).

\section{Unsatisfactory samples in each crop analyzed}

The choice of which crops would be analyzed in a given year was based on consumption data provided through the Family Budget Survey (Pesquisa de Orçamentos Familiares - POF), made between 2008-2009, and on commercial availability of these foods, which is why some crops were not analyzed in certain years. Between the years 2001 to 2007 , the strawberry stood out as the crop with the highest amount of unsatisfactory samples, but as of 2008, bell pepper started to be included in the analyzes and took first place (Table 1).

Table 1: Total unsatisfactory samples* by crop analyzed by the Program for Analysis of Pesticide Residues in Food (PARA) (2001-2018) in percentage (\%).

\begin{tabular}{|c|c|c|c|c|c|c|c|c|c|c|c|c|c|}
\hline CROP & $\begin{array}{r}2001- \\
2002\end{array}$ & 2003 & 2004 & 2005 & 2006 & 2007 & 2008 & 2009 & 2010 & 2011 & 2012 & $\begin{array}{l}2013- \\
2015\end{array}$ & $\begin{array}{c}2017- \\
2018\end{array}$ \\
\hline Pineapple & $\mathrm{N}$ & $\mathrm{N}$ & $\mathrm{N}$ & $\mathrm{N}$ & $\mathrm{N}$ & $\mathrm{N}$ & 9.47 & 44.10 & 32.80 & $\mathrm{~N}$ & 41.00 & 15.42 & 11.81 \\
\hline Zucchini & $\mathrm{N}$ & $\mathrm{N}$ & $\mathrm{N}$ & $\mathrm{N}$ & $\mathrm{N}$ & $\mathrm{N}$ & $\mathrm{N}$ & $\mathrm{N}$ & $\mathrm{N}$ & $\mathrm{N}$ & 48.00 & 77.78 & $\mathrm{~N}$ \\
\hline Lettuce & 8.64 & 6.67 & 14.00 & 46.46 & 28.68 & 40.00 & 19.80 & 38.40 & 54.20 & 43.00 & 45.00 & 36.38 & 30.07 \\
\hline Garlic & $\mathrm{N}$ & $\mathrm{N}$ & $\mathrm{N}$ & $\mathrm{N}$ & $\mathrm{N}$ & $\mathrm{N}$ & $\mathrm{N}$ & $\mathrm{N}$ & $\mathrm{N}$ & $\mathrm{N}$ & $\mathrm{N}$ & $\mathrm{N}$ & 4.66 \\
\hline Rice & $\mathrm{N}$ & $\mathrm{N}$ & $\mathrm{N}$ & $\mathrm{N}$ & $\mathrm{N}$ & $\mathrm{N}$ & 4.41 & 27.20 & 7.40 & 16.00 & 1.00 & 4.16 & 4.56 \\
\hline Banana & 6.53 & 2.22 & 3.59 & 3.14 & $\mathrm{~N}$ & 4.32 & 1.03 & 3.50 & $\mathrm{~N}$ & $\mathrm{~N}$ & $\mathrm{~N}$ & 2.79 & $\mathrm{~N}$ \\
\hline Potato & 22.20 & 8.65 & 1.79 & 0.00 & 0.00 & 1.36 & 2.00 & 1.20 & 0.00 & $\mathrm{~N}$ & $\mathrm{~N}$ & 4.45 & $\mathrm{~N}$ \\
\hline Sweet Potato & $\mathrm{N}$ & $\mathrm{N}$ & $\mathrm{N}$ & $\mathrm{N}$ & $\mathrm{N}$ & $\mathrm{N}$ & $\mathrm{N}$ & $\mathrm{N}$ & $\mathrm{N}$ & $\mathrm{N}$ & $\mathrm{N}$ & $\mathrm{N}$ & 8.89 \\
\hline Beet & $\mathrm{N}$ & $\mathrm{N}$ & $\mathrm{N}$ & $\mathrm{N}$ & $\mathrm{N}$ & $\mathrm{N}$ & $\mathrm{N}$ & 32.00 & 32.60 & $\mathrm{~N}$ & $\mathrm{~N}$ & 26.05 & 14.56 \\
\hline Onion & $\mathrm{N}$ & $\mathrm{N}$ & $\mathrm{N}$ & $\mathrm{N}$ & $\mathrm{N}$ & $\mathrm{N}$ & 2.91 & 16.30 & 3.10 & $\mathrm{~N}$ & $\mathrm{~N}$ & 6.87 & $\mathrm{~N}$ \\
\hline Carrot & 0.00 & 0.00 & 19.54 & 11.90 & $\mathrm{~N}$ & 9.93 & 30.39 & 24.80 & 49.60 & 67.00 & 33.00 & 35.52 & 39.66 \\
\hline
\end{tabular}




\begin{tabular}{c|c|c|c|c|c|c|c|c|c|c|c|c|c}
\hline Chayote & $\mathrm{N}$ & $\mathrm{N}$ & $\mathrm{N}$ & $\mathrm{N}$ & $\mathrm{N}$ & $\mathrm{N}$ & $\mathrm{N}$ & $\mathrm{N}$ & $\mathrm{N}$ & $\mathrm{N}$ & $\mathrm{N}$ & $\mathrm{N}$ & 9.03 \\
\hline Collard & $\mathrm{N}$ & $\mathrm{N}$ & $\mathrm{N}$ & $\mathrm{N}$ & $\mathrm{N}$ & $\mathrm{N}$ & $\mathrm{N}$ & 44.20 & 31.90 & $\mathrm{~N}$ & $\mathrm{~N}$ & 34.21 & $\mathrm{~N}$ \\
\hline Beans & $\mathrm{N}$ & $\mathrm{N}$ & $\mathrm{N}$ & $\mathrm{N}$ & $\mathrm{N}$ & $\mathrm{N}$ & 2.92 & 3.00 & 6.50 & 6.00 & 7.30 & 7.20 & $\mathrm{~N}$ \\
\hline Cornmeal & $\mathrm{N}$ & $\mathrm{N}$ & $\mathrm{N}$ & $\mathrm{N}$ & $\mathrm{N}$ & $\mathrm{N}$ & $\mathrm{N}$ & $\mathrm{N}$ & $\mathrm{N}$ & $\mathrm{N}$ & 2.90 & 1.78 & $\mathrm{~N}$ \\
\hline Guava & $\mathrm{N}$ & $\mathrm{N}$ & $\mathrm{N}$ & $\mathrm{N}$ & $\mathrm{N}$ & $\mathrm{N}$ & $\mathrm{N}$ & $\mathrm{N}$ & $\mathrm{N}$ & $\mathrm{N}$ & $\mathrm{N}$ & 45.57 & 42.40 \\
\hline Orange & 1.41 & 0.00 & 4.91 & 4.71 & 0.00 & 6.04 & 14.85 & 10.30 & 12.20 & $\mathrm{~N}$ & 28.00 & 8.06 & 13.61 \\
\hline Apple & 4.04 & 3.67 & 4.96 & 3.05 & 5.33 & 2.90 & 3.92 & 5.30 & 8.90 & $\mathrm{~N}$ & 8.00 & 10.60 & $\mathrm{~N}$ \\
\hline Papaya & 19.50 & 37.56 & 2.50 & 0.00 & $\mathrm{~N}$ & 17.21 & 17.31 & 38.80 & 30.40 & 20.00 & $\mathrm{~N}$ & 17.45 & $\mathrm{~N}$ \\
\hline Manioc & $\mathrm{N}$ & $\mathrm{N}$ & $\mathrm{N}$ & $\mathrm{N}$ & $\mathrm{N}$ & $\mathrm{N}$ & $\mathrm{N}$ & $\mathrm{N}$ & $\mathrm{N}$ & $\mathrm{N}$ & $\mathrm{N}$ & 2.77 & $\mathrm{~N}$ \\
\hline Mango & $\mathrm{N}$ & $\mathrm{N}$ & $\mathrm{N}$ & $\mathrm{N}$ & $\mathrm{N}$ & $\mathrm{N}$ & 0.99 & 8.10 & 4.00 & $\mathrm{~N}$ & $\mathrm{~N}$ & 15.98 & 9.14 \\
\hline Strawberry & 46.03 & 54.55 & 39.07 & $\mathrm{~N}$ & 37.68 & 43.62 & 36.05 & 50.80 & 63.40 & $\mathrm{~N}$ & 59.00 & 72.61 & $\mathrm{~N}$ \\
\hline Cucumber & $\mathrm{N}$ & $\mathrm{N}$ & $\mathrm{N}$ & $\mathrm{N}$ & $\mathrm{N}$ & $\mathrm{N}$ & $\mathrm{N}$ & 54.80 & 57.40 & 44.00 & 42.00 & 29.77 & $\mathrm{~N}$ \\
\hline Bell Pepper & $\mathrm{N}$ & $\mathrm{N}$ & $\mathrm{N}$ & $\mathrm{N}$ & $\mathrm{N}$ & $\mathrm{N}$ & 64.36 & 80.00 & 91.80 & 90.00 & $\mathrm{~N}$ & 88.89 & 81.90 \\
\hline Cabbage & $\mathrm{N}$ & $\mathrm{N}$ & $\mathrm{N}$ & $\mathrm{N}$ & $\mathrm{N}$ & $\mathrm{N}$ & 8.82 & 20.50 & 6.30 & $\mathrm{~N}$ & $\mathrm{~N}$ & 16.09 & $\mathrm{~N}$ \\
\hline Tomato & 26.10 & 0.00 & 7.36 & 4.38 & 2.01 & 44.72 & 18.27 & 32.60 & 16.30 & 12.00 & 16.00 & 32.05 & 34.81 \\
\hline Grapeat & $\mathrm{N}$ & $\mathrm{N}$ & $\mathrm{N}$ & $\mathrm{N}$ & $\mathrm{N}$ & $\mathrm{N}$ & $\mathrm{N}$ & $\mathrm{N}$ & $\mathrm{N}$ & $\mathrm{N}$ & $\mathrm{N}$ & 7.51 & $\mathrm{~N}$ \\
\hline & $\mathrm{N}$ & $\mathrm{N}$ & $\mathrm{N}$ & $\mathrm{N}$ & $\mathrm{N}$ & $\mathrm{N}$ & 32.67 & 56.40 & $\mathrm{~N}$ & 27.00 & 29.00 & 74.55 & 26.96 \\
\hline
\end{tabular}

$\mathrm{N}=$ crop not analyzed. * The samples were considered unsatisfactory when they presented pesticides not authorized for use on the crop, and / or pesticides above the maximum residue limit established, with the sum of these two parameters providing the total of unsatisfactory samples.

Source: Program for Analysis of Pesticide Residues in Food - PARA (2001-2018).

As showed on Table 1 the crops with the higher amount of unsatisfactory samples presented frequently more than $80 \%$ of the total samples, being the case of strawberry and bell pepper. Banana and mango present a low amount of unsatisfatory samples also with low range.

\section{Crops with a greater amount of unauthorized pesticides and above the maximum residue limit as of PARA 2009}

As shown in Figure 3 the reports made available from 2009 onwards showed individualized results on crops containing unauthorized pesticides and above the maximum residue limit. The samples that showed the highest amount of pesticides above MRL were pineapple, zucchini, lettuce, collard, apple, papaya, mango, strawberry, cucumber, bell pepper, tomato and grape, in which strawberry had the highest number with $26.11 \%$. Comparing data it was noted that most of the samples considered unsatisfactory were those that presented residues of pesticides not authorized for the crop, where the one with the highest number was bell pepper with $88.07 \%$. 
Figure 3: Samples that showed the highest amount of unauthorized pesticides (\%) according to the Program for Analysis of Pesticide Residues in Food (PARA) (2009-2018).

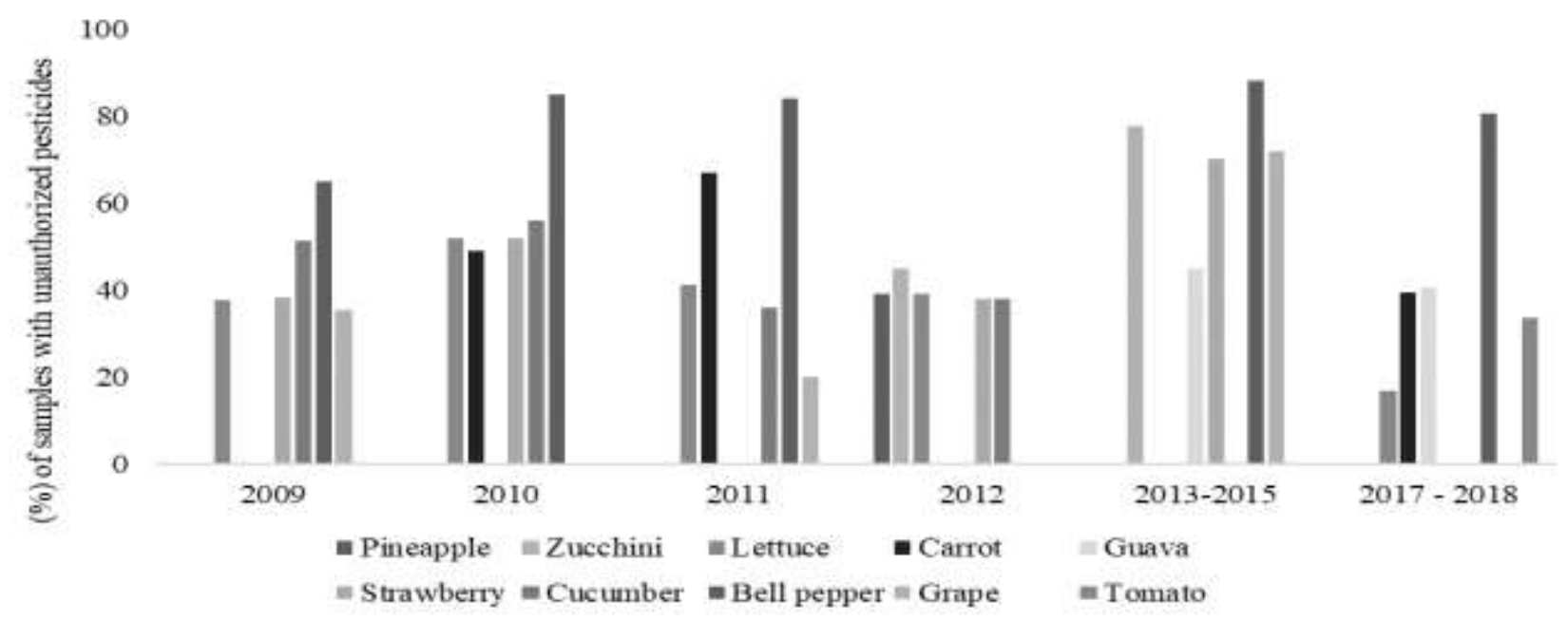

Source: Program for Analysis of Pesticide Residues in Food - PARA (2009-2018).

\section{Pesticides with higher numbers of detections in unsatisfactory samples}

The analysis of the reports showed which were the pesticides with the highest number of detections in unsatisfactory samples during the years 2008 to 2018, as shown in Figure 4, and it is possible to observe that the pesticides with the highest number of detections in unsatisfactory samples were: chlorpyrifos, acephate, carbendazim and metamidophos, detected in 1092, 1062, 773, and 307 samples respectively, during the aforementioned period.

Figure 4: Pesticides with the highest number of detections in unsatisfactory samples per year according to the Program for Analysis of Pesticide Residues in Food (PARA) (2008 - 2018).

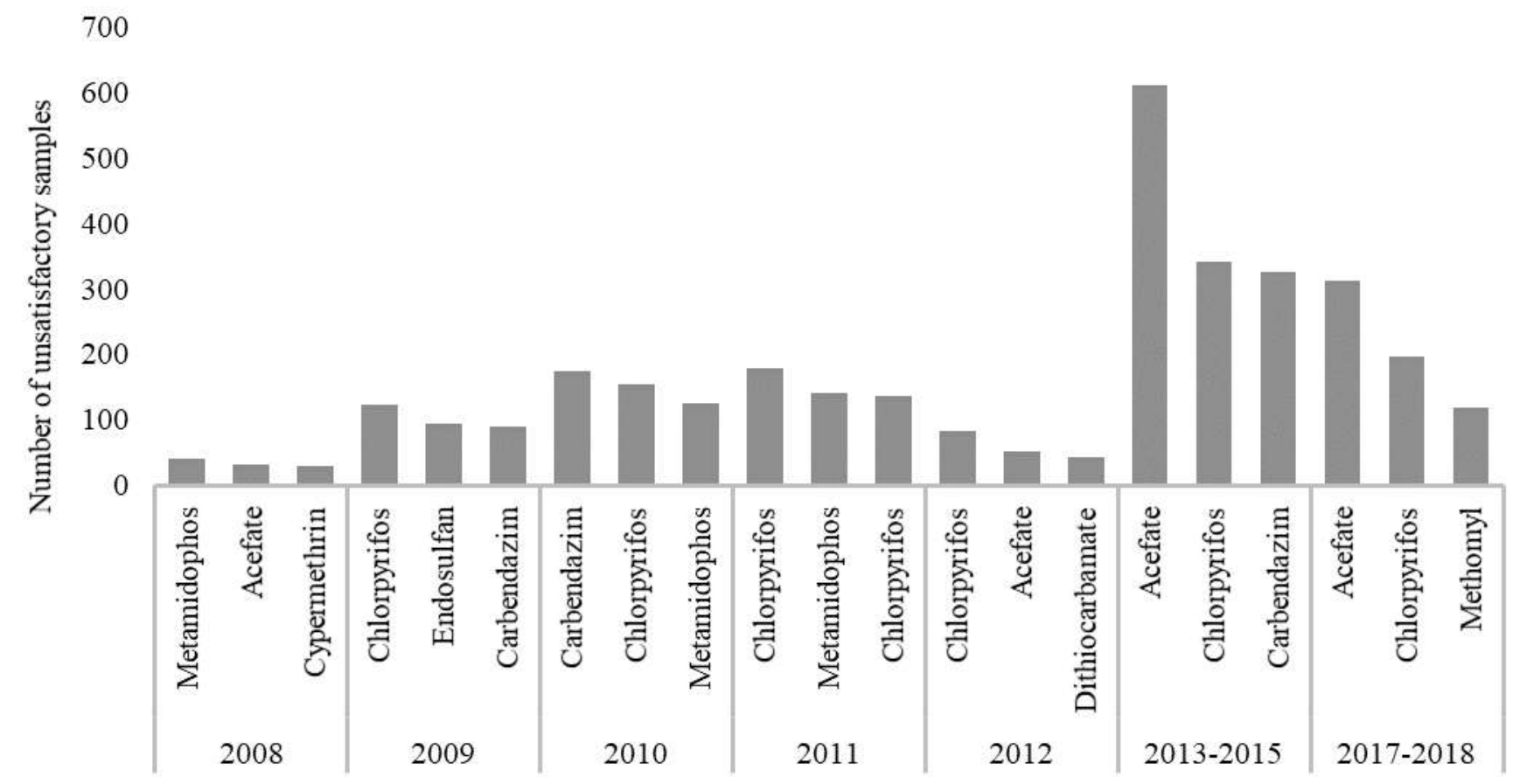

Source: Program for Analysis of Pesticide Residues in Food (PARA) (2008 - 2018). 
The report for the years 2001 to 2007 presented only data on the percentage of samples with unsatisfactory results, without distinguishing between samples that were unsatisfactory due to the use of pesticides not authorized for the crop, or because they contain pesticides above the MRL. They also did not provide information on pesticides that were detected, and that information only emerged from the 2008 report.

The multi-residue analytical method or specific validated methodologies were used by PARA in the analysis of the samples. It is important to highlight the advantages of the multiresidue method, which are: fast, efficient, and based on the simultaneous analysis of different active ingredients and metabolites of pesticides in the same sample. However, it cannot be applied for the analysis of some active ingredients, such as glyphosate, which requires specific methodologies, which overloaded the laboratories of PARA, thus only after the last report (2017-2018) did this pesticide begin to be analyzed (ANVISA, 2016). Glyphosate also presents a particularity; of the 14 total crops analyzed in 2017-2018, this compound was analyzed in only 3 crops (rice, mango and grape), with $2 \%$ of the samples being considered unsatisfactory (ANVISA, 2019).

\section{Discussion}

Bell pepper presented the highest percentage of unsatisfactory samples since its inclusion in the crops analyzed by PARA in 2008 (excluding the year 2012, in which it was not part of the analyzed crops), reaching approximately 92\% of unsatisfactory samples in the year 2010 (Table 1). Samples with pesticides above the MRL in bell peppers were found by Chu et al. (2019), in an analysis of this fruit from the Shandong province of China, with 5.35\% of the samples analyzed showing this irregularity, with emphasis on the detection of the pesticide Bifenthrin.

From 2001 to 2007, the crop with the highest percentage of unsatisfactory samples was strawberry, however since 2008, with the inclusion of bell pepper, it occupied the second and third positions taking turns with cucumbers and grapes (Table 1), which became included in the analyzes in 2009 and 2008 respectively. Regarding strawberries in Poland, only the pesticides allowed in the country for cultivation were researched; the samples were both fresh and frozen strawberries and products made with the fruit, and of the total samples, $36 \%$ did not present residues, while in $60 \%$ of the samples the residues did not exceed the MRL (Sójka et al., 2015). As for bell peppers and cucumbers, a similar result was found by Jallow and collaborators (2017), who investigated the presence of pesticide residues in fruits and vegetables of common consumption in Kuwait, and demonstrated that tomato $(88 \%)$, bell pepper $(83 \%)$ and cucumber $(87 \%)$ presented the largest number of samples contaminated with pesticide residues.

Similar to the present study, a study by Poulsen et al. (2017) analyzed reports from the Danish food monitoring program in the period 2004 - 2011, which in addition to fruits, vegetables, and cereals, also included foods of animal origin. A total of 17,309 samples were collected over the period described, of which only $2.6 \%$ showed residues above the permitted level, being mostly fruits. Differently from the results published by PARA, in which the biggest problem detected was in relation to samples with unauthorized pesticide residues, the Danish article does not present this information and only samples with pesticide residues above the MRL are cited.

Poulsen et al. (2017) also found dithiocarbamate and carbendazim as the pesticides that most frequently appeared in the samples exceeding MRLs, a result that corroborates with the present study in which carbendazim is also cited as one of the most frequent detections. The study also makes an observation regarding the tracking of the samples; Denmark, being a small country imports many foods, and through the tracking it was possible to notice that the vast majority of the food with pesticide residues originated from other countries, including Brazil. It showed that $100 \%$ of apples and 55\% of grape samples from Brazil had pesticide residues. 
Corresponding to the results found in the present article, a study by Słowik-borowiec et al. (2016), when analyzing the presence of pesticide residues in fruit from farms in southeastern Poland in the period from 2012 to 2015, also obtained as a result a greater amount of irregular detections related to the presence of unauthorized pesticides for the crop $(6 \%$ of the samples analyzed), but did not find pesticides above the MRL.

Similar to the results of the present research, Bhandari and collaborators (2019) in a study carried out in Nepal found residues of pesticides in $100 \%$ of the tomato samples, of which $44 \%$ were with residues above the European MRL, with carbendazim and chlorpyrifos being the most frequently found pesticides. Chlorpyrifos was also the most frequently found pesticide (25.9\% of the samples analyzed) in another study conducted in Argentina. This research showed that $65 \%$ of Argentine samples had pesticide residues, of which more than half had residues above the MRL (Loughlin et al., 2018). Another study carried out with peaches in China found pesticide residues in $92.3 \%$ of the samples, with carbendazim being found in $60.6 \%$ of the total samples (Li et al., 2018).

Since data regarding pesticides detected in the samples were not disclosed in the first report of PARA, from 2001 to 2007, when carrying out the analysis of the subsequent reports that contained this information, and which were published between the years 2008 to 2018, it was observed that the pesticides with the highest number of detections in unsatisfactory samples were: chlorpyrifos, acephate, carbendazim and metamidophos. Additionally, as glyphosate was included in the analyzes only in the last report (2017-2018) and, in view of the widespread use of this pesticide (IBAMA, 2019), it was also included. Therefore, the following was a survey of the literature on the possible toxic effects that exposure to these pesticides could cause to human health.

\section{Chlorpyrifos}

Chlorpyrifos is an insecticide, formicide and acaricide of the class of organophosphates; it is authorized by ANVISA and EPA (Environmental Protection Agency) in United States. Classified toxicologically as class II, highly toxic (ANVISA, 2015), chlorpyrifos was the $10^{\text {th }}$ best-selling active ingredient in Brazil for 2019, according to the Brazilian Institute for the Environment and Renewable Natural Resources (Instituto Brasileiro do Meio Ambiente e dos Recursos Naturais Renováveis IBAMA, 2019).

A study by $\mathrm{Li}$ and collaborators (2019) demonstrated that chlorpyrifos decreases the concentrations of luteinizing hormone (LH) and follicle stimulating hormone (FSH), as well as testosterone. In addition, it also alters the intestinal microbiota and promotes a drop in the adrenaline concentration in animals exposed starting in the newly weaned period. Even at doses considered non-toxic, chlorpyrifos had effects on the breast tissue of rats at chronic exposure, which resulted in adenosis, in addition to breast hyperplasia and decreased LH levels after administration of the pesticide (Ventura et al., 2016). On april 2021 the Federal Court ruled that EPA must ban Chlorpirifos as it has been linked to neurological damage in children (DENNIS, 2021).

\section{Acephate}

Acephate is an insecticide and acaricide of the class of organophosphates; its use is authorized by ANVISA and EPA, classified as class III, moderately toxic (ANVISA, 2016). Data from the sales report of IBAMA for the year 2019 presented acephate as the $4^{\text {th }}$ best-selling active ingredient in Brazil, with more than 28 thousand tons (IBAMA, 2019).

In a study by Dhanushka and Peiris (2017), in which sperm collected from healthy men were exposed to different concentrations of acephate, it was shown that groups exposed to $100 \mu \mathrm{g} / \mathrm{mL}$ and $200 \mu \mathrm{g} / \mathrm{mL}$ showed a significant decrease in sperm motility, in addition to having their integrity and capacity affected, which suggests that exposure to this compound can 
cause infertility. Another study, this time carried out in pregnant women and infants, reported the development of glucose intolerance, in addition to weight gain in those exposed to acephate compared to the control group (Ribeiro et al., 2016). The same study also demonstrated an increase in the susceptibility of offspring from mothers who were exposed to acephate during pregnancy and lactation, to the development of type 2 diabetes as adults.

\section{Carbendazim}

Carbendazim is a fungicide of the benzimidazole class; it is authorized by ANVISA, and its toxicological classification is class III, moderately toxic (ANVISA, 2019a). Carbendazim is unauthorized in the European Union, and in the United States it can only be used ornamental plants (EFSA, 2010; USEPA, 2014). In Brazil the pesticide is currently under reassessment (Brazil, 2019).

A study conducted with rats showed that exposure to carbendazim decreased sperm concentration and motility, in addition to interrupting spermatogenesis (Liu et al., 2019). Another study by Lisovska and collaborators (2017), showed the carcinogenic potential in chronic use of carbendazim, with different doses of the pesticide being administered for 104 weeks, and the most common sites of tumor appearance were: thyroid, breasts, pituitary, hematopoietic system, and testicles, which demonstrated the carcinogenic potential of this pesticide and its potent disrupting action of the endocrine system. EFSA (European Food Safety Authority) concluded that carbendazim also presented genotoxic efects (EFSA, 2010).

\section{Metamidophos}

Metamidophos is an insecticide and acaricide belonging to the class of organophosphates, its toxicological classification is class I, extremely toxic. Despite being banned by ANVISA since 2011 (ANVISA, 2011) and EFSA, methamidophos is among the pesticides that most appeared, which can be explained as it is a metabolite of acephate.

Studies carried out on rats have shown that metamidophos affects spermatogenesis (Ortega-Olvera et al., 2018). Urióstegui-Acosta and collaborators (2014) evaluated its effects at different stages, with the animals being evaluated 1, 28, and 45 days after treatment with metamidophos, and sperm motility and viability showed a significant reduction in the groups of 28 and 45 days. The group evaluated one day after treatment showed an inhibition of more than $50 \%$ of acetylcholinesterase. Metamidophos also had effects on the heart muscle after the intraperitoneal injection, also the plasma cholinesterase activity was reduced by $80 \%$ (Maretto et al., 2012). Another study indicated that metamidophos affected the functioning of the brain, generating depressive behavior in rats exposed to the active ingredient via ingestion (Lima et al., 2011).

\section{Glyphosate}

Glyphosate is a non-selective active ingredient that makes up the basis of some pesticides with herbicidal activity; its toxicological classification is class IV, and its use is permitted by ANVISA and EFSA in several crops (ANVISA, 2019b; Reis, 2019; EFSA, 2017). Annual bulletins released by IBAMA showed that since 2009, glyphosate is the best-selling pesticide in Brazil. The most recent data are from 2019 in which sales of this active ingredient exceeded 217 thousand tons, a value four times higher than the second best-selling active ingredient in the same period (IBAMA, 2019). The commercialization numbers of glyphosate can be explained by the introduction of transgenic soybean, cotton, and corn seeds resistant to glyphosate in the 1990s; it is estimated that $98 \%$ of the soy produced in Brazil is transgenic (Reis, 2019).

It is important to mention that despite being the best-selling pesticide in Brazil, and now researched by PARA, glyphosate does not yet appear among the most commonly found pesticides, whether in unsatisfactory samples or not (Figure 4). 
The International Agency for Research on Cancer (IARC) has classified glyphosate as a probable carcinogen for humans (IARC, 2015). Studies on the toxic effects of glyphosate showed that this pesticide induced histological changes in the liver (Benedetti et al., 2004), promoted toxic effects on the digestive system and altered microbial composition (Tang et al., 2020), affected ovarian function and the secretion of hormones during pregnancy in rats (Ren et al., 2018). Oxidative stress increased and reproductive hormones decreased, effects that were increased in animals which received a combination of pesticides (Astiz et al., 2009). Not only did glyphosate showed toxic effects, but these effects were significantly increased by the presence of adjuvants in glyphosate-based herbicide formulations, which demonstrated that adjuvants were not inert (Benachour \& Séralini, 2009; Nagy et al., 2019).

\section{Exposure to different pesticides}

It is important to highlight that a single sample may present residues of two or more pesticides, which is a concern when these pesticides have the same mechanism of action and this can be enhanced. The only reports issued by PARA that showed this data were the 2013 - 2015 report with $37.4 \%$ and the one for the 2017 and 2018 with $34.9 \%$ of the samples presenting residues of two or more pesticides simultaneously (ANVISA, 2019; ANVISA, 2016). The presence of more than one residue in the same sample can be explained by the use of different types of pesticides against a variety of pests, in addition, there are also formulations containing more than one pesticide (Noblat et al., 2021).

$\mathrm{Fu}$ and collaborators ( $\mathrm{Fu}$ et al., 2019) found synergistic effects in chronic low-dose use between chlorpyrifos and carbofuran against neural cells and inhibition of cell proliferation, resulting in the induction of apoptosis. In a study carried out in China, hair samples were collected from women living in urban areas and in each sample, residues of 25 to 50 pesticides/metabolites were found (Peng et al., 2020).

In general, the presence of pesticides in food activates a warning signal, especially when they are above the MRLs or are found in crops for which they are not authorized, the latter being the main reason for samples to be considered unsatisfactory in the present study. Pesticides have toxic health effects through different types of exposure, whether occupational, maternal, paternal, prenatal, postnatal, environmental, or oral. According to Mostafalou and Abdollahi (2017), pesticides proved to be capable of inducing several types of cancer, altering development and metabolism, in addition to being toxic to the lungs, the nervous and reproductive systems.

This study had some limitations, as follows: absence of standardization in the analyzes made by PARA, both with regard to the crops analyzed in each year, and in the periodicity in which the reports were made available; the year 2016 did not present a report and the last report covering the period from 2017 to 2018 was only made available at the end of 2019. There was also no uniformity in the researched information, data that should have been present in all reports only appeared in one, when it did, making it difficult to deepen the discussion in several points.

\section{Conclusion}

In view of the variations and the drastic reduction in the number of crops/food samples analyzed in the last report of PARA, there is a clear need to strengthen its actions, with greater investments, especially with regard to the laboratories responsible for the analysis and transport of the foods. In addition, it is possible to realize that a more intense inspection is necessary, so that the main problem found, the use of pesticides not authorized for the crop, is resolved. Furthermore, the pesticides most used in Brazil in an irregular way have demonstrated the potential to trigger serious damage to human health, being extremely important that there is also a greater inspection of the indiscriminate and/or illegal use of these products, as well as educational activities for rural workers about the application and the right protective equipment, reducing cases of both 
occupational and food poisoning. It is also important to make the general population aware of the risks pesticides can cause. Given the above research, further studies are needed to explore the possible toxic effects of chronic food exposure to these pesticide residues, in order to ensure the safe consumption of these foods.

\section{Acknowledgement}

The authors would like to thank Universidade Federal de São João del-Rei (UFSJ), Campus Centro-Oeste Dona Lindu (CCO), for the support offered to research carried out. This study was financed in part by the Coordenação de Aperfeiçoamento de Pessoal de Nível Superior - Brasil (CAPES) - Finance Code 001.

\section{References}

ANVISA, Agência Nacional de Vigilância Sanitária. (2008). Programa de Análise de Resíduos de Agrotóxicos em Alimentos - PARA. http://portal.anvisa.gov.br/documents/111215/117818/nota\%2Btecnica\%2B-\%2Bresultados\%2Bpara\%2B2008.pdf/78967b71-4df4-4b47-b5b3-6d71de5 $4 b 3923$

ANVISA, Agencia Nacional de Vigilância Sanitária. (2011). Resolução n 1, de 14 de Janeiro de 2011. Regulamento técnico para o ingrediente ativo Metamidofós em decorrência da reavaliação toxicológica.

ANVISA, Agencia Nacional de Vigilância Sanitária (2015). Monografia Clorpirifós, Resolução RE n ${ }^{\circ}$.346 de 17/08/15. http://portal.anvisa.gov.br/documents/111215/117782/C20\%2B\%2BClorpirif\%25C3\%25B3s.pdf/f8ddca3d-4e17-4cea-a3d2-d8c5babe36ae

ANVISA, Agencia Nacional de Vigilância Sanitária. (2016a). Relatório Das Análises De Amostras Monitoradas No Período De 2013 A 2015.

ANVISA. (2016b). Monografia Acefato, Resolução RE nº 3.083 de 17/11/16. http://portal.anvisa.gov.br/documents/111215/117782/A02++Acefato/651fe170-9e1f-409f-93a3-b31b99e426b2?version=1.1

ANVISA. (2019a). Monografia Carbendazim. Resolução RE n ${ }^{\circ} 2.752$ de 02/10/19. http://portal.anvisa.gov.br/documents/111215/117782/c24.pdf/a019eb91b52d-492d-8140-ae82f54d5698

ANVISA. (2019b). Monografia Glifosato. Resolução RE nº 3.133 de 06/11/19. http://portal.anvisa.gov.br/documents/111215/117782/G01\%2B\%2BGlifosato. pdf/6a549ab8-990c-4c6b-b421-699e8f4b9ab4

Astiz, M., de Alaniz, M. J. T., \& Marra, C. A. (2009). The impact of simultaneous intoxication with agrochemicals on the antioxidant defense system in rat. Pesticide Biochemistry and Physiology, 94(2), 93-99. https://doi.org/10.1016/j.pestbp.2009.03.005

Benachour, N., \& Séralini, G.-E. (2009). Glyphosate Formulations Induce Apoptosis and Necrosis in Human Umbilical, Embryonic, and Placental Cells. Chemical Research in Toxicology, 22(1), 97-105. https://doi.org/10.1021/tx800218n.

Benedetti, A. s. L. et al. (2004). The effects of sub-chronic exposure of Wistar rats to the herbicide Glyphosate-Biocarb®. Toxicology Letters, 153(2), 227232. https://doi.org/10.1016/j.toxlet.2004.04.008.

Bhandari, G. et al. (2019). Pesticide residues in Nepalese vegetables and potential health risks. Environmental Research, 172, 511-521. https://doi.org/10.1016/j.envres.2019.03.002.

Brazil. Ministério da Saúde. (2019). Edital de chamamento no 1, de 19 de dezembro de 2019. Diário Oficial da União. Ministério da Saúde. 2019.

Carneiro, F. F. (2015). Dossiê ABRASCO: um alerta sobre os impactos dos agrotóxicos na saúde. Escola Politécnica de Saúde Joaquim Venâncio. Expressão Popular.

Chiu, Y. H. et al. (2015). Fruit and vegetable intake and their pesticide residues in relation to semen quality among men from a fertility clinic. Human Reproduction, 30(6), 1342-1351. https://doi.org/10.1093/humrep/dev064.

Chiu, Y.H. et al. (2018). Association Between Pesticide Residue Intake From Consumption of Fruits and Vegetables and Pregnancy Outcomes Among Women Undergoing Infertility Treatment With Assisted Reproductive Technology. JAMA Internal Medicine, 178(1), 17-26. 10.1001/jamainternmed.2017.5038.

Chu, Z. et al. (2019). Residue levels and health risk of pesticide residues in bell pepper in Shandong. Food Additives \& Contaminants: Part A, 36(9), 13851392. 10.1080/19440049.2019.1628362

DATASUS. (2020). Intoxicação exógena - Notificações registradas no SINAN. http://tabnet.datasus.gov.br/cgi/tabcgi.exe?sinannet/cnv/Intoxbr.def

Dennis, B. (2021). Federal court rules EPA must ban pesticide linked to harm in children — or prove it is safe. https://www.washingtonpost.com/climateenvironment/2021/04/29/federal-court-rules-epa-must-ban-pesticide-linked-harm-children-or-prove-it-is-safe/

Dhanushka, M. A. T., \& Peiris, L. D. C. (2017). Cytotoxic and Genotoxic Effects of Acephate on Human Sperm. Journal of Toxicology, $2017,3874817$. https://doi.org/10.1155/2017/3874817 
EFSA. European Food Safety Authority (2010). Conclusion on the Peer Review of th Pesticide Risk Assessment of the Active Substance Carbendazim. EFSA Journal, 8(5):1598. 2010.

EFSA. European Food Safety Authority (2017). Commission Implementing Regulation (Eu) 2017/2324 of 12 December 2017: Renewing the approval of the active substance glyphosate in accordance with Regulation (EC) No 1107/2009 of the European Parliament and of the Council concerning the placing of plant protection products on the market, and amending the Annex to Commission Implementing Regulation (EU) No 540/2011. Official Journal of the European Union. 2017.

Elias, C. de S. R., et al. (2012). Quando chega o fim? uma revisão narrativa sobre terminalidade do período escolar para alunos deficientes mentais. SMAD Revista Eletrônica Saúde Mental Álcool E Drogas (Edição Em Português), 8(1), 48-53. https://doi.org/10.11606/issn.1806-6976.v8i1p48-53

Fu, D.-J. et al. (2019). Mechanisms of synergistic neurotoxicity induced by two high risk pesticide residues - Chlorpyrifos and Carbofuran via oxidative stress. Toxicology in Vitro, 54, 338-344. https://doi.org/10.1016/j.tiv.2018.10.016.

Gómez-Ramos, M. d. M. et al. (2020). Pesticide residues evaluation of organic crops. A critical appraisal. Food Chemistry: X, 5, 100079. https://doi.org/10.1016/j.fochx.2020.100079.

Greenpeace Brasil. (2019). Um governo com mais fome de veneno. https://www.greenpeace.org/brasil/blog/um-governo-com-fome-de-veneno/

Grigori, P. (2019). Apicultores brasileiros encontram meio bilhão de abelhas mortas em três meses: Casos foram detectados no Rio Grande do Sul, Santa Catarina, São Paulo e Mato Grosso do Sul. Análises laboratoriais identificaram agrotóxicos em cerca de $80 \%$ dos enxames mortos no RS. https://reporterbrasil.org.br/2019/03/apicultores-brasileiros-encontram-meio-bilhao-de-abelhas-mortas-em-tres-meses/

Grigori, P. (2021). Bolsonaro bate o próprio recorde: 2020 é o ano com maior aprovação de agrotóxicos da história. https://apublica.org/2021/01/bolsonarobate-o-proprio-recorde-2020-e-o-ano-com-maior-aprovacao-de-agrotoxicos-da-historia/

IARC. International Agency for Research on Cancer (2015). IARC Monographs Volume 112: evaluation of five organophosphate insecticides and herbicides. IBAMA. (2019). Relatórios de comercialização de agrotóxicos. http://www.ibama.gov.br/agrotoxicos/relatorios-de-comercializacao-de-agrotoxicos.

Jallow, M. F. A. et al. (2017). Monitoring of Pesticide Residues in Commonly Used Fruits and Vegetables in Kuwait. International Journal of Environmental Research and Public Health, 14(8). https://doi.org/10.3390/ijerph14080833.

Knežević, Z., \& Serdar, M. (2011). Risk assessment of human exposure to pesticides in food. Archives of Industrial Hygiene and Toxicology, 62(3), 269-278. https://doi.org/10.2478/10004-1254-62-2011-2112.

Leão, G. da C., \& Ferreira, J. C. de S. (2021). Nutrition and food changes in the middle of the pandemic COVID-19. Research, Society and Development, 10(7), e11610716602. https://doi.org/10.33448/rsd-v10i7.16602.

Li, J.-W. et al. (2019). Age- and diet-specific effects of chronic exposure to chlorpyrifos on hormones, inflammation and gut microbiota in rats. Pesticide Biochemistry and Physiology, 159, 68-79. https://doi.org/10.1016/j.pestbp.2019.05.018.

Li, Z. et al. (2018). A monitoring survey and dietary risk assessment for pesticide residues on peaches in China. Regulatory Toxicology and Pharmacology, 97, 152-162. https://doi.org/10.1016/j.yrtph.2018.06.007.

Lima, C. S. et al. (2011). Exposure to methamidophos at adulthood adversely affects serotonergic biomarkers in the mouse brain. NeuroToxicology, 32(6), 718-724. https://doi.org/10.1016/j.neuro.2011.08.002.

Lisovska, V. et al (2017). Endocrine disruption and carcinogenesis: Evaluation of neoplasms in endocrine organs of rat in Carbendazim carcinogenic chronic study. Toxicology Letters. 280, S167. https://doi.org/10.1016/j.toxlet.2017.07.467.

Liu, J. et al (2019). Low dose carbendazim disrupts mouse spermatogenesis might Be through estrogen receptor related histone and DNA methylation. Ecotoxicology and Environmental Safety, 176, 242-249. https://doi.org/10.1016/j.ecoenv.2019.03.103.

Loughlin, T. M. et al. (2018). Pesticide residues in fruits and vegetables of the argentine domestic market: Occurrence and quality. Food Control, 93, 129-138. https://doi.org/10.1016/j.foodcont.2018.05.041.

Ludke, M. \& Andre, M. E. D. A. (1986). Pesquisas em educação: uma abordagem qualitativa. EPU, 1986.

Maretto, G. X. et al. (2012). Acute exposure to the insecticide O,S-dimethyl phosphoramidothioate (methamidophos) leads to impairment of cardiovascular reflexes in rats. Ecotoxicology and Environmental Safety, 80, 203-207. https://doi.org/10.1016/j.ecoenv.2012.03.001.

Mostafalou, S., \& Abdollahi, M. (2017). Pesticides: an update of human exposure and toxicity. Archives of Toxicology, 91(2), 549-599. 10.1007/s00204-0161849-x https://doi.org/10.1007/s00204-016-1849-x.

Nagy, K. et al. (2019). Comparative cyto- and genotoxicity assessment of glyphosate and glyphosate-based herbicides in human peripheral white blood cells. Environmental Research, 179, 108851. https://doi.org/10.1016/j.envres.2019.108851

Noblat, A. K. de M. et al., (2021). Impact of pesticides on food: A literature review. Research, Society and Development, 10(6), e36110614504. https://doi.org/10.33448/rsd-v10i6.14504

Nougadère A. et al. (2020). Dietary exposure to pesticide residues and associated health risks in infants and young children - Results of the French infant total diet study. Environment international. 2020. 137:105529. https://doi.org/10.1016/j.envint.2020.105529

Ortega-Olvera, J. M. et al. (2018). The organophosphate pesticide methamidophos opens the blood-testis barrier and covalently binds to ZO-2 in mice. Toxicology and Applied Pharmacology, 360, 257-272. https://doi.org/10.1016/j.taap.2018.10.003 
Research, Society and Development, v. 10, n. 12, e95101220085, 2021

(CC BY 4.0) | ISSN 2525-3409 | DOI: http://dx.doi.org/10.33448/rsd-v10i12.20085

Peng, F.-J. et al. (2020). Exposure to multiclass pesticides among female adult population in two Chinese cities revealed by hair analysis. Environ Int, 138, 105633. https://doi.org/10.1016/j.envint.2020.105633

Pirsaheb, M. et al. (2015). Organochlorine pesticides residue in breast milk: a systematic review. Medical journal of the Islamic Republic of Iran, 29, 228-228. PMID: 26478886

Poulsen, M. E. et al. (2017). Results from the Danish monitoring programme for pesticide residues from the period 2004-2011. Food Control, 74, 25-33. https://doi.org/10.1016/j.foodcont.2016.11.022

Reis, V. (2019). Entenda o que é o glifosato, o agrotóxico mais vendido do mundo. https://www.abrasco.org.br/site/noticias/movimentos-sociais/entenda-oque-e-o-glifosato-o-agrotoxico-mais-vendido-do-mundo/40996/

Ren, X. et al. (2018). Effects of glyphosate on the ovarian function of pregnant mice, the secretion of hormones and the sex ratio of their fetuses. Environmental Pollution, 243, 833-841. https://doi.org/10.1016/j.envpol.2018.09.049

Ribeiro, T. A. et al. (2016). Acephate exposure during a perinatal life program to type 2 diabetes. Toxicology, 372, 12-21. https://doi.org/10.1016/j.tox.2016.10.010

Słowik-Borowiec, M. et al. (2016). Occurrence of pesticide residues in fruiting vegetables from production farms in south-eastern region of Poland. Roczniki Panstwowego Zakladu Higieny, 67(4), 359-365.

Sójka, M. et al. (2015). Pesticide residue levels in strawberry processing by-products that are rich in ellagitannins and an assessment of their dietary risk to consumers. NFS Journal, 1, 31-37. https://doi.org/10.1016/j.nfs.2015.09.001

Tang, Q. et al. (2020). Glyphosate exposure induces inflammatory responses in the small intestine and alters gut microbial composition in rats. Environmental Pollution, 261, 114129. https://doi.org/10.1016/j.envpol.2020.114129

USEPA. United States Environmental Protection Agency (2014). Thiophanate-Methyl and Carbendazim (MBC). Human Health Assessment Scoping Document in Support of Registration Revies. Memorandum. 2014.

Urióstegui-Acosta, M. et al. (2014). Methamidophos alters sperm function and DNA at different stages of spermatogenesis in mice. Toxicology and Applied Pharmacology, 279(3), 391-400. https://doi.org/10.1016/j.taap.2014.06.017

Ventura, C. et al. (2016). Pesticide chlorpyrifos acts as an endocrine disruptor in adult rats causing changes in mammary gland and hormonal balance. The Journal of Steroid Biochemistry and Molecular Biology, 156, 1-9. https://doi.org/10.1016/j.jsbmb.2015.10.010 